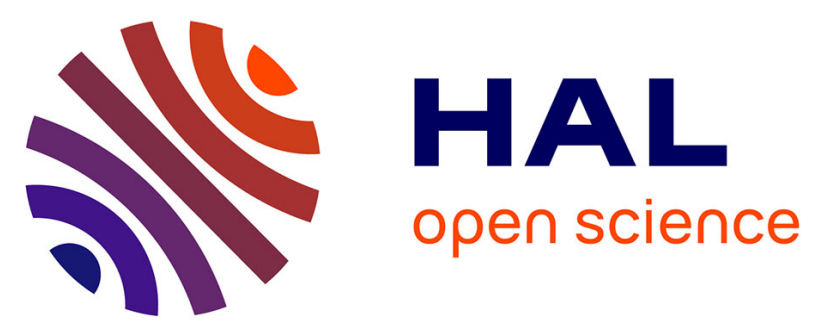

\title{
Preliminary results on trace element levels in three species of seabirds from the western Indian Ocean
}

Jessica Kojadinovic, Matthieu Le Corre, Richard P. Cosson, Marc Salamolard, Paco Bustamante

\section{- To cite this version:}

Jessica Kojadinovic, Matthieu Le Corre, Richard P. Cosson, Marc Salamolard, Paco Bustamante. Preliminary results on trace element levels in three species of seabirds from the western Indian Ocean. Ostrich: Journal of African Ornithology, 2007, 78 (2), pp.435-441. 10.2989/OSTRICH.2007.78.2.50.130 . hal-00474025

\section{HAL Id: hal-00474025 \\ https://hal.science/hal-00474025}

Submitted on 18 Apr 2010

HAL is a multi-disciplinary open access archive for the deposit and dissemination of scientific research documents, whether they are published or not. The documents may come from teaching and research institutions in France or abroad, or from public or private research centers.
L'archive ouverte pluridisciplinaire HAL, est destinée au dépôt et à la diffusion de documents scientifiques de niveau recherche, publiés ou non, émanant des établissements d'enseignement et de recherche français ou étrangers, des laboratoires publics ou privés. 


\title{
Preliminary results on trace element levels in three species of seabirds from the western Indian Ocean
}

\author{
Jessica Kojadinovic ${ }^{1,2,4}$, Matthieu Le Corre ${ }^{1}$, Richard P Cosson ${ }^{2}$, Marc Salamolard ${ }^{3}$ and Paco \\ Bustamante $^{4}$ \\ ${ }^{1}$ ECOMAR, Université de La Réunion, 15 avenue René Cassin, 97715 Saint-Denis de La Réunion, France \\ ${ }^{2}$ LBM, Université de Nantes, 2 chemin Houssinière, 44300 Nantes, France \\ ${ }^{3}$ SEOR, 377 rue Dumesnil d'Engente, 97440 Saint André, Ile de La Réunion, France \\ ${ }^{4}$ LBEM, Université de La Rochelle, 22, Avenue Michel Crépeau, 17042 La Rochelle, France \\ * Corresponding author, e-mail: jessica.kojadinovic@isomer.univ-nantes.fr
}

\begin{abstract}
As top predators of pelagic food webs, marine birds naturally bioaccumulate essential and nonessential elements. Levels of arsenic (As), cadmium $(\mathrm{Cd})$, copper $(\mathrm{Cu})$, iron $(\mathrm{Fe})$, mercury $(\mathrm{Hg})$, manganese $(\mathrm{Mn})$, selenium $(\mathrm{Se})$ and zinc $(\mathrm{Zn})$ were determined in the liver, kidneys and muscles of three species of marine birds found on Réunion Island: Barau's Petrel (Pterodroma baraui), Audubon's Shearwater (Puffinus lherminieri bailloni) and the White-tailed Tropicbird (Phaethon lepturus). The study of the 89 birds sampled put forth variations of the elemental levels between organs, age groups (juveniles versus adults) and species. Adult Barau's Petrels showed the highest values of $\mathrm{Hg}$ and $\mathrm{Cd}$. This study offers a first glimpse of the levels of impregnation of eight trace elements in top predators of the western Indian Ocean and brings answers to certain questions related to the processes of bioaccumulation in marine top predators of the tropical Indian Ocean.
\end{abstract}

RESUME: Situés au sommet des réseaux trophiques pélagiques, les oiseaux marins bioaccumulent naturellement des éléments essentiels et non-essentiels tout au long de leur vie. La mesure des teneurs en arsenic (As), cadmium $(\mathrm{Cd})$, cuivre $(\mathrm{Cu})$, fer $(\mathrm{Fe})$, mercure $(\mathrm{Hg})$, manganèse $(\mathrm{Mn})$, sélénium $(\mathrm{Se})$ et zinc $(\mathrm{Zn})$ a été effectuée dans le foie, les reins et les muscl es de trois espèces d'oiseaux de l'île de La Réunion, le pétrel de Barau (Pterodroma baraui), le puffin de baillon (Puffinus lherminieri bailloni) et le paille-en-queue à brin blanc (Phaethon lepturus). L'étude des 89 oiseaux échantillonnés fait apparaître des variations des teneurs métalliques entre les organes, les classes d'âge (juvéniles vs adultes), ainsi qu'entre les espèces, les pétrels de Barau adultes ayant les plus fortes teneurs en $\mathrm{Hg}$ et $\mathrm{Cd}$. Cette étude offre ainsi, un premier aperçu des niveaux d'imprégnation de 8 éléments traces chez des prédateurs supérieurs de l'Océan Indien occidental tropical et propose des éléments de réponses quant aux processus de bioaccumulation chez ces espèces endémiques des Mascareignes.

\section{Introduction}

Marine birds are known to be an efficient 'tool' for investigating the marine environment (Cherel and Weimerskirch 1995, Barrett and Krasnov 1996, Furness and Camphuysen 1997). They are widely used as bioindicators of contaminants such as metals (Furness et al. 1993, Monteiro and Furness 1995, Gray 2002). In spite of the large variety and number of seabirds present in the southern hemisphere, most studies in this field have been carried out on species inhabiting the northern hemisphere. The few studies that have been conducted on metals in the southern hemisphere have focused on Chile (Ochoa-Acuna et al. 2002), New Zealand (Stewart et al. 1999a), Gough Island (Muirhead and Furness 1988), the Kerguelen Islands (Bocher et al. 2003) and the Antarctic area (Szefer et al. 1993, Ancora et al. 2002, Gonzalez-Solis et al. 2002). The tropical zone of the Indian Ocean has, up to the present day, received very little attention from researchers with reference to biocenoses metal contamination. Only one study related to living organisms was found in published literature (Kureishy et al. 1979). This may be due to the fact that the southern oceans are often considered as less polluted than the northern ones (Stewart et al. 1999a). However, the study of unpolluted sites can be of great interest since it allows an estimation of the 'background' levels of contaminants to be made and can thus be used as a reference in space and time.

This paper presents a baseline study of the levels of metal contamination in three marine birds that reproduce on Réunion Island and thus gives a first estimate of the levels of metal contamination in the seabird trophic chains of the western part of the tropical Indian Ocean. Because of its limited industrialisation and its geographical isolation, Réunion Island is considered as relatively unpolluted by human activities and could constitute, in this manner, a valuable in situ laboratory for the follow up of possible future variations of contaminant levels in the environment. Moreover, this study brings elements of information on bioaccumulation of metals in three protected seabirds chosen for their contrasting dietary ecology. Barau's Petrel is a pelagic bird that feeds almost exclusively on cephalopods. Although the White-tailed Tropicbird is not quite as pelagic as Barau's Petrel, its diet is also mostly composed of cephalopods. Aububon's Shearwater is a coastal foraging bird that feeds as much on cephalopods as it does on fish. 
Accordingly, the distribution of three non-essential elements (mercury, cadmium and arsenic) and five essential elements (copper, iron, manganese, selenium and zinc) was examined in the liver, kidney and muscle of the sampled birds. The variations of the contamination levels were explained by various factors, thus enabling the comparison of individuals characterised by similar features.

\section{Materials and methods \\ Study site and species}

The seabirds used in this study originated from colonies established on Réunion Island $\left(21^{\circ} 7^{\prime} \mathrm{S}, 5^{\circ} 33^{\prime} \mathrm{E}\right)$, a French territory $\left(2512 \mathrm{~km}^{2}\right)$ located $700 \mathrm{~km}$ east of Madagascar in the western Indian Ocean.

Barau's Petrel (Pterodroma baraui), described in 1963, is endemic to Réunion Island, where its population is estimated at 4 000-6 500 pairs (Probst et al. 2000). This pelagic bird is present on the island from September (courtship and mating) through to May (fledglings' first flight) (Bretagnolle and Attié 1991). The eggs are laid in November. During its reproduction season Barau's Petrels scatter to feed in the tropical and subtropical waters as far as several hundred kilometres south of Réunion Island. Its diet consists of $98 \% 1$ cephalopods (Stenoteuthis oualaniensis and Taonius sp.) and 2\% fish (Gigan and Lebon, pers. comm.). From March to September, Barau's Petrel leaves Réunion waters and migrates towards the north and the east of the Indian Ocean (Stahl and Bartle 1991, Barré et al. 1996).

The pantropical and non-migratory Aububon's Shearwater (Puffinus lherminieri bailloni) is found only on the islands of Réunion and Europa2 (Barré et al. 1996, Le Corre 2000). Three thousand to 5000 pairs breed in 235 colonies located in the interior of Réunion Island (at altitudes ranging from 50 to $1500 \mathrm{~m}$ ) as well as on the coastal cliffs (Bretagnolle et al. 2000). This species reproduces all year around with an increase of activity during the austral spring and summer (Barré et al. 1996). During the breeding season, Aububon's Shearwater does not seem to drift away more than $50 \mathrm{~km}$ from the coast. It is therefore considered as a coastal foraging bird (Bailey 1968, Jaquemet et al. 2004). During that time, its diet consists of 50\% Stenoteuthis oualaniensis and $50 \%$ fish (Gigan and Lebon, pers. comm.).

Two thousand to 5000 White-tailed Tropicbirds (Phaethon lepturus) nest in ravines or on coastal cliffs of Réunion Island. They do not form true colonies (Le Corre, pers. comm.). This indigenous species breeds on the island all year long. During this period its diet consists of $80 \%$ Stenoteuthis oualaniensis and $20 \%$ fish, mainly of the Mollidae and Dactylopteridae families (Gigan and Lebon, pers. comm.). Outside their reproduction period individuals scatter in the pantropical waters of the Indian Ocean (Barré et al. 1996). During that time, dietary habits of these three birds remain unknown.

\section{Sample preparation}

A total of 89 seabirds (36 Barau's Petrels, 38 Audubon's Shearwaters and 15 White-tailed Tropicbirds) were collected and stored in plastic bags at $-20^{\circ} \mathrm{C}$ by the 'Réunion Ornithological Society' (SEOR) between 2000 and 2004. Most Procellariiformes (Barau's Petrels and Audubon's Shearwaters) are 2-3 month old fledglings. These young birds are attracted to artificial lights during their first flight out to sea and often die from collisions with light sources such as street lamps. Of the hundreds of fledgling petrels and shearwaters found stranded annually, 90\% are rescued successfully (Le Corre et al. 2001). The remaining 10\% are usually found dead or fatally injured. Poaching was one of the main causes of the death of White-tailed Tropicbirds. Since these birds were found before or shortly after their death, we shall not consider that the conditions in which the birds died had an influence on their metal levels (Wenzel and Adelung 1996).

Maturity (juvenile or adult) was determined by characteristic features of the beak and the feathers. Since these birds do not show any sexual dimorphism, their sex was determined during dissection. Samples of the liver, kidneys and pectoral muscles were removed and refrozen prior to analysis. During the dissection, the muscular condition was estimated on a scale from 1 to 3 in relation to the shape of the pectoral muscles, ' 1 ' referring to well-developed muscles and '3' to atrophied muscles (Bolton et al. 1991).

To prepare for metal analysis, the liver, kidneys and muscles were blended, dried in an oven at $55^{\circ} \mathrm{C}$ to constant mass for $72 \mathrm{~h}$ and ground to a fine powder.

\section{Metal analysis}


Accuracy and reproducibility of the preparation were tested by preparing 11 replicates of dogfish liver (Dolt-2) and muscle (DORM-2) reference standards (National Research Council, Canada) and 11 blanks along with each set of samples. The sample preparation was done in 'metal-free' conditions. Glass and plastic utensils were washed with detergent, plunged in a bath of mixed nitric (35) and chlorhydric (50) acids for a minimum of $24 \mathrm{~h}$, rinsed three times in deionised (Milli-Q quality) water and dried in an oven at $50^{\circ} \mathrm{C}$ before use.

For arsenic (As), cadmium $(\mathrm{Cd})$, copper $(\mathrm{Cu})$, iron $(\mathrm{Fe})$, manganese $(\mathrm{Mn})$, selenium $(\mathrm{Se})$ and zinc $(\mathrm{Zn})$ determination, two aliquots of approximately 200 or $300 \mathrm{mg}$ of each dried sample were digested in $3.5 \mathrm{ml}$ of $15 \mathrm{~N}$ supra-pure nitric acid at $60^{\circ} \mathrm{C}$ for $48 \mathrm{~h}$ on a hot plate before being diluted to $10 \mathrm{ml}$ with deionised (Milli-Q quality) water. They were then analysed by Inductive Coupled Plasma Atomic Emission Spectrometry (ICP/AES). Total mercury $(\mathrm{Hg})$ analyses were carried out with an Advanced Mercury Analyser (ALTEC AMA 254), which does not require acid digestion of the samples. Aliquots ranging from 5 to $20 \mathrm{mg}$ of dried sample were directly analysed by the AMA 254. In the apparatus, the samples were dried, heated under oxygen atmosphere for $3 \mathrm{~min}$ and amalgamated on a gold net. Then the net was heated to liberate the amalgamated $\mathrm{Hg}$, which was measured by absorption spectrophotometry. Element levels are expressed in $\mu \mathrm{g} / \mathrm{g}-1$ of dry weight (d.w.).

\section{Statistical analysis}

The combined influence of species and age on the levels of the eight metals in the three tissues (pectoral muscles, liver and kidneys) was studied by means of two-way ANOVAs and Bonferroni tests. To study the influence of the 'tissue' factor on the metallic levels, one-way repeated measures ANOVAs and Friedman tests were used for each metal in order to compare the levels of each metal in each tissue. Consistently, the normality of the data was tested and the results of the appropriate test considered. Besides, correlation tests were used to put forth the correlations between various metals levels in each tissue and correlations between the levels of a metal in the three tissues.

\section{Results}

The levels of As, $\mathrm{Cd}, \mathrm{Cu}, \mathrm{Fe}, \mathrm{Hg}, \mathrm{Mn}, \mathrm{Se}$ and $\mathrm{Zn}$ in the different tissues of the three species are shown in Table 1 .

\section{Inter-tissue comparisons}

The inter-tissue comparisons were done on juvenile petrels, juvenile shearwaters and adult tropicbirds because of a lack of data for the other subgroups. The reader should keep this in mind while observing the results presented in Table 1. The 'tissue' factor seemed to have a major influence on the metal levels which, in most cases, varied significantly between the liver, kidneys and muscles. The general trend, in all three species, showed that the liver was a privileged destination for $\mathrm{As}, \mathrm{Cu}, \mathrm{Fe}, \mathrm{Hg}, \mathrm{Mn}$ and $\mathrm{Zn}$. Cadmium and Se accumulated mostly in the kidney.

In spite of the metal-burden variations between tissues, the existence of correlations between various metals levels in a given tissue and correlations between the levels of a metal in the three tissues were put forth. Copper, $\mathrm{Mn}, \mathrm{Se}$ and $\mathrm{Zn}$ were correlated in juvenile shearwaters' kidneys ( $\mathrm{r}^{2}$ ranging from 0.766 to 0.936$)$. Correlations were also established in adult tropicbirds between $\mathrm{Mn}, \mathrm{Fe}, \mathrm{Cu}$, and $\mathrm{Zn}$ in the liver $\left(\mathrm{r}^{2}\right.$ ranging from 0.408 to 0.909 ) and $\mathrm{Mn}, \mathrm{Se}, \mathrm{Cu}$ and $\mathrm{Zn}$ in the muscles ( $\mathrm{r}^{2}$ ranging from 0.621 to 0.913 ).

\section{Combined influence of phylogeny and age on metal level variations}

The comparison of adults and juveniles of different species was made possible by the study of the combined influence of phylogeny and age on elemental concentrations. Significant differences in elemental levels were found among species (p-values are presented in Table 1). Selenium and Cd burdens were significantly higher in adult petrels than in adult tropicbirds in liver and muscle $(\mathrm{p} \approx 0.0001)$. The levels of these elements in Audubon's Shearwaters were intermediate. The juvenile tropicbirds accumulated significantly more hepatic and muscular Zn, Mn and Fe than the juvenile Procellariiformes. There were globally no notable differences between species for $\mathrm{Cu}$ and As. Mercury appeared to be highly influenced by both the species and the age factors, with particularly high levels in adult petrels.

There were other significant differences in metal levels between adult and juvenile birds (Table 1). In Procellariiformes, Cd levels were significantly higher in adults $(\mathrm{p} \approx 0.0001)$. Arsenic, $\mathrm{Cu}$, hepatic and muscular $\mathrm{Zn}$ as well as muscular Fe levels were higher in the juvenile tropicbirds than in the adults. The influence of age 
on $\mathrm{Mn}$ in the tropicbirds was inconsistent since levels seemed to increase with age in the muscle and decrease in the liver. No significant differences were found in the tropicbirds.

\section{Discussion}

\section{Metallic levels: comparison with other studies}

Published results of metal levels in free-living seabird tissues vary considerably with a large number of factors including species, age and location (Garcia-Fernandez et al. 1996, Stewart et al. 1997, Stewart et al. 1999a). Most ecotoxicological works are based on the study of adults, as they are better 'integrators' of the environmental contamination over a longer period of time. A thorough comparison between our results and published data is thus difficult due to a very limited number of publications concerning juveniles. Moreover, the Phaethon genus has received very limited attention regarding elemental bioaccumulation. Nevertheless, the data obtained in this study is of the same order of magnitude, or, in most cases, lower than that found for petrels and shearwaters studied on other islands such as Gough, the Azores or New Zealand (Muirhead and Furness 1988, Stewart et al. 1994, Stewart et al. 1997a, Stewart et al. 1999b). Metal burdens in juvenile Audubon's Shearwaters are similar to those found in juvenile Cory's Shearwaters from the Azores islands (Stewart et al. 1997a). Mercury levels in adult Barau's Petrels (29.5 and $19.8 \mu \mathrm{g} \mathrm{g}^{-1} \mathrm{~d}$.w. in the liver and kidney, respectively) resemble those found in the Great-winged Petrel (Pterodroma macroptera) from New Zealand (21.3 and $28.3 \mu \mathrm{g}$ $\mathrm{g}^{-1}$ d.w. in the liver and kidney, respectively), and are intermediate between hepatica levels (15.3 $\mu \mathrm{g} \mathrm{g}^{-1}$ d.w.) in the Kerguelen Petrel ( $P$. brevirostris incerta), and the Soft-Plumage (P. mollis) and Atlantic (P. incerta) petrels from Gough Island (69.9 and $93.2 \mu \mathrm{g} \mathrm{g}^{-1}$ d.w., respectively). It can be suspected that, as in other species of the Pterodroma genus, Barau's Petrel might also have a tendency of bioaccumulating $\mathrm{Hg}$.

\section{Influencing factors of metal level variations}

The results of this preliminary study seem to indicate that tissue, taxonomy and age have major impacts on metal levels. Other sources of variation also commonly reported are: (a) geographical location, (b) season, (c) interspecific sources such as size, life span and migratory habits and (d) intraspecific sources such as sex, reproductive status and nutritional status (Kim et al. 1998, Stewart et al. 1997, Stewart et al. 1999a). Variations between tissues As it has often been demonstrated, trace elements are not all identically distributed in birds' bodies (Furness and Rainbow 1990, Furness et al. 1993, Thompson et al. 1996). In Table 2 various tissues are classified according to their 'ability' to concentrate trace elements. The allocation of $\mathrm{Hg}, \mathrm{Zn}, \mathrm{Fe}$ and Cd burdens in the three studied tissues of the Réunion birds reflects the usual trends (Table 2). Liver and kidneys are considered long-term storage tissues for $\mathrm{Cd}$ and $\mathrm{Hg}$ (Walsh 1990) implicating that large birds with a long life span accumulate high burdens of these elements (Stewart et al. 1999a). This is true in Procellariiformes, for which the albatrosses are the best example (Hindell et al. 1999), and seems to apply to this study where Barau's Petrel is the largest and most contaminated of the two procellariiforme species. The distribution of $\mathrm{Cu}$ in the shearwaters and the tropicbirds' tissues does not follow the expected trend. In this study, $\mathrm{Cu}$ burdens are equivalent in the liver and in the muscles. This allocation pattern has, however, already been observed, although not explained, in the Common Diving Petrel (Pelecanoides urinatrix), the South Georgian Diving Petrel (Pelecanoides georgicus) and the Antarctic Prion (Pachyptila desolata) from the Kerguelen archipelago (Bocher et al. 2003). Selenium also differs from the usual distribution pattern since it is mostly accumulated in the kidneys of the studied birds. There are few data on the distribution of Mn among seabird tissues. It was found mainly in liver and kidney of Procellariiformes studied by Kim et al. (1998) and mainly in the liver of the Réunion birds from this study.

Very often the metal burden in its target tissue is positively correlated with its level in the other tissues. This trend was verified for As, Cd, Hg, Mn and Se in Barau's Petrel, As, Cd and $\mathrm{Hg}$ in Audubon's Shearwater and $\mathrm{Hg}, \mathrm{Mn}$ and $\mathrm{Zn}$ in the White-tailed Tropicbird. The target tissue can, in these cases, be considered as representative of the body burden of the metal (Monteiro and Furness 1995).

\section{Variations due to age}

High degrees of variation have been observed for three non-essential elements ( $\mathrm{Cd}, \mathrm{Hg}$, and $\mathrm{As}$ ) and for one essential one (Mn), especially in the muscles (Table 1). Various studies indicate that $\mathrm{Cd}$ is generally much more concentrated in adults than it is in juveniles and that this element's burden can vary up to fourfold during the different phases of the reproduction season (Thompson et al. 1996, Lock et al. 1997). Within age categories, Fe, $\mathrm{Zn}, \mathrm{Cu}$ and Se have low coefficients of variation $(\leq 10 \%)$. These essential elements appear to be regulated by the organism (Thompson et al. 1996, Kim et al. 1998). High levels of essential metals in juveniles, as it is the case here for Fe and $\mathrm{Zn}$ in the juvenile tropicbirds, have been cited in other studies (Kim et al. 1998, Stewart et al. 
1999a). Indeed, during growth, juveniles accumulate essential elements in their liver to meet increased nutritional needs (Thompson et al. 1996) and to survive the fast caused by the abandonment of the fledglings by their parents several days before the young's first flight.

Variations between species

The three studied species differ mainly by the differential 'behaviour' of essential elements in relation to age between the tropicbird, on one side, and the petrel and shearwater on the other, and by the larger levels of $\mathrm{Hg}$ and $\mathrm{Cd}$ in Barau's Petrel.

Tropicbirds belong to the Phaethontidae family, whereas the two other species are Procellariiformes. The different trends in essential metal accumulation patterns observed between juvenile White-tailed Tropicbirds and juvenile Procellariiformes may be explained by phylogenic differences, or indirectly through their different dietary habits, although this hypothesis is to be verified on larger samples.

Although Procellariiformes clearly concentrate trace elements, resulting in much higher metal burden than many other seabirds (Walsh 1990), phylogeny explains relatively little of the interspecific variations within the order (Stewart et al. 1999a). The high Hg level found in adult Barau's Petrel may be explained by the specificity of its diet. Of the three birds, only Barau's Petrel feeds on the Taonius genus. These are mesopelagic cephalopods that live at depths of 500-700m (Clarke 1986, Nesis 1987). It is thought that Barau's Petrel feeds on floating carcasses of these squids. The deep, poorly oxygenated waters house the process of $\mathrm{Hg}$ methylation, which consists of the transformation of $\mathrm{Hg}$ from an inorganic to an organic form more easily absorbed by living organisms (Furness and Camphuysen 1997, Thompson et al. 1998, Neff 2002). This explains the higher Hg levels found in pelagic marine birds with respect to terrestrial birds (Monteiro et al. 1996, Thompson et al. 1998) and could explain the higher $\mathrm{Hg}$ levels found in Barau's Petrel. Procellariiformes are also known for having high Cd levels due to their diet being composed essentially of cephalopods, which have a high capacity of Cd bioaccumulation (Koli and Whitmore 1986, Bustamante et al. 1998a,b). This seems to be the case in Réunion Procellariiformes and especially in Barau's Petrel since $98 \%$ of its diet is composed of cephalopods (Gigan and Lebon, pers. comm.). It would be interesting to study the $\mathrm{Hg}$ and $\mathrm{Cd}$ burdens of the various prey species of the three birds in order to confirm these hypotheses.

\section{Conclusion}

The three species analysed in this study had rather low levels of trace elements. As commonly observed in birds, it seems that the elemental levels of these Réunion seabirds vary between tissues, age groups (juveniles versus adults), species and diet. Nevertheless, all results presented here must be confirmed by the study of a larger number of adults. Possible correlations between elemental burdens in the internal tissues and in the feathers will be studied in view of using the feathers as a monitoring tissue. Further studies will also include the analysis of trace element burdens in more species of top predators, including other marine birds and pelagic fish as well as their prey.

\section{Notes}

${ }^{1}$ The diet compositions are given in percentage of the total number of prey.

${ }^{2}$ Europa is the most southern French territory of the Mozambique Channel. It is located at $22^{\circ} 20^{\prime} \mathrm{S}$ and $40^{\circ} 21 \mathrm{E}$, $1650 \mathrm{~km}$ from Réunion island, and comprises an area of $28 \mathrm{~km}^{2}$.

\section{Acknowledgments}

This research was supported by the Conseil Général de La Réunion. J Kojadinovic also benefited from support from the Conseil Régional de La Réunion and the Fonds Social Européen through a PhD grant. The authors would like to thank Elisabeth Robert, Manuel Rouquette, Patricia Grondin and Nadia Ghanem for their help in the tissue preparation and Carine Churlaud, member of the Centre Commun d'Analyse (CCA) of La Rochelle, for her assistance with the analyses on the ICP/AES. We would also like to thank the numerous volunteers who actively participate in the SEOR Petrel rescue programme, as well as the referees for their helpful comments on the manuscript.

\section{References}

Ancora S, Volpi V, Olmastroni S, Focardi S and Leonzio C 2002. Assumption and elimination of trace elements in adélie penguins from Antartica: a preliminary study. Marine Environmental Research 54: 341-344 
Bailey RS 1968. The pelagic distribution of seabirds in the Western Indian Ocean. Ibis 110: 492-493

Barré N, Barau A and Jouanin C 1996. Oiseaux de la Réunion. Les Editions du Pacifique, Paris, France

Barrett RT and Krasnov YV 1996. Recent responses to changes in stocks of prey species by seabirds breeding in the southern Barents Sea. ICES Journal of Marine Science 53: 713-722

Bocher P, Caurant F, Cherel Y, Miramand P and Bustamante P 2003. Influence of the diet on the bioaccumulation of heavy metals in zooplankton-eating petrels at Kerguelen archipelago, Southern Indian Ocean. Polar Biology 26: 759-767

Bolton M, Monaghan P and Houston DC 1991. An improved technique for estimating pectoral muscle protein condition from body measurements of live gulls. Ibis 133: 264-270

Bretagnolle V and Attié C 1991. Status of Barau's Petrel (Pterodroma baraui) colony sites, breeding population and taxonomic affinities. Colonial Waterbirds 14: 25-33

Bretagnolle V, Attié C and Mougeot F 2000. Audubon's Shearwaters Puffinus lherminieri on Réunion Island, Indian Ocean: behaviour, census, distribution, biometrics and breeding biology. Ibis 142: 399-412

Bustamante P, Caurant F, Fowler S and Miramand P 1998a. Cephalopods as a vector for the transfer of cadmium to top marine predators in the north-east Atlantic Ocean. Science of the Total Environment 220: 71-80

Bustamante P, Cherel Y, Caurant F and Miramand P 1998b. Cadmium, copper and zinc in octopuses from Kerguelen Islands, Southern Indian Ocean. Polar Biology 19: 264-271

Cherel Y and Weimerskirch H 1995. Seabirds as indicators of marine resources: black-browed albatrosses feeding on ommastrephid squids in Kerguelen waters. Marine Ecology Progress Series 129: 295-300

Clarke MR 1986. A Handbook for the Identification of Cephalopod Beaks. Sierra Club Books, Oxford, UK

Furness R and Camphuysen K 1997. Seabirds as monitors of the marine environment. ICES Journal of Marine Science 54: 726-737

Furness RW and Rainbow PS (eds) 1990. Heavy Metals in the Marine Environment. CRC Press, Boca Raton, Florida, USA

Furness RW, Greenwood JJD, Jarvis PJ, Lehr Brisbin I, Ormerod SJ, Tyler SJ, Montevecchi WA, Baillie SR, Crick HQP, Marchant JH and Peach WJ 1993. Birds as Monitors of Environmental Changes. Chapman and Hall, London, UK

Garcia-Fernandez AJ, Sanchez-Garcia JA, Gomez-Zapata M and Luna A 1996. Distribution of cadmium in blood and tissuesof wild birds. Archives Environmental Contamination and Toxicology 30: 252-258

González-Solís J, Sanpera C and Ruiz X 2002. Metals and selenium as bioindicators of geographic and trophic segregation in giant petrels Macronectes spp. Marine Ecology Progress Series 244: 257-264

Gray J 2002. Biomagnification in marine systems: the perspective of an ecologist. Marine Pollution Bulletin 45: $46-52$

Hindell MA, Brothers N and Gales R 1999. Mercury and cadmium concentrations in the tissues of three species of southern albatrosses. Polar Biology 22: 102-108

Jaquemet S, Le Corre M and Weimerskirch H 2004. Seabird community structure in a coastal tropical environment: importance of natural factors and fish aggregating devices (FADs). Marine Ecology Progress Series 268: 281-292

Kim EY, Goto R, Tanaka S and Tatsukawa R 1998. Distribution of 14 elements in tissues and organs of oceanic seabirds. Archives of Environmental Contamination and Toxicology 33: 638-645 
Koli AK and Whitmore R 1986. Distribution pattern of cadmium in different types of shellfish species. Environment International 12: 559-561

Kureishy TW, George MD and Sen Gupta R 1979. Total mercury content in some marine fish from the Indian Ocean. Marine Pollution Bulletin 10: 357-360

LeCorre M 2000. Taxonomic affinities of Audubon's Shearwater from Europa Island. Condor 102: 187-190

LeCorre M, Ollivier A, Ribes S and Jouventin P 2001. Light induced mortality of petrels: a 4-year study from Réunion Island (Indian Ocean). Biological Conservation 105: 93-102

Lock JW, Thompson DR, Furness RW and Bartle JA 1997. Metal concentration in seabirds of the New Zealand region. Marine Pollution Bulletin 75: 289-300

Monteiro LR and Furness RW 1995. Seabirds as monitors of mercury in the marine environment. Water, Air and Soil Pollution 80: 851-870

Monteiro LR, Costa V, Furness RW and Santos RS 1996. 'Mercury concentrations in prey fish indicate enhanced bioaccumulation in mesopelagic environments'. Marine Ecology Progress Series 141: 21-25

Muirhead SJ and Furness RW 1988. 'Heavy metal concentrations in the tissues of seabirds from Gough Island, South Atlantic Ocean'. Marine Pollution Bulletin 19: 278-283

Neff JM 2002. Bioaccumulation in Marine Organisms. Elsevier, Amsterdam, The Netherlands

Nesis KN 1987. Cephalopods of the World. TFH Publications, Neptune City, New Jersey, USA

Ochoa-Acuna H, Sepulveda MS and Gross TS 2002. Mercury in feathers from Chilean birds: influence of location, feeding strategy, and taxonomic affiliation. Marine Pollution Bulletin 44: $340-345$

Probst JM, LeCorre M and Thebault C 2000. Breeding habitat and conservation priorities in Pterodroma baraui, an endangered gadfly petrel of the Mascarene archipelago. Biological Conservation 93: 135-138

Stahl J and Bartle JA 1991. Distribution, abundance and aspects of the pelagic ecology of Barau's Petrel (Pterodroma baraui) the south-west Indian Ocean. Notornis 38: 211-225

Stewart FM, Monteiro LR and Furness RW 1997. Heavy metal concentrations in Cory's shearwater, Calonectris diomedea, fledglings from the Azores, Portugal. Bulletin of Environmental Contamination Toxicology 58: 115-122

Stewart FM, Phillips RA, Bartle JA, Craig J and Shooter D 1999. Influence of phylogeny, diet, moult schedule and sex on heavy metal concentrations in New Zealand Procellariiformes. Marine Ecology Progress Series 178: 295-305

Stewart F, Phillips R, Catry P and Furness R 1997. Influence of species, age and diet on mercury concentrations in Shetland seabirds. Marine Ecology Progress Series 151: 237-244

Stewart FM, Thompson DR, Furness RW and Harrison N 1994. Seasonal variation in heavy metal levels in tissues of Common Guillemots, Uria aalge from northwest Scotland. Archives of Environmental Contamination and Toxicology 27: 168-175

Szefer P, Pempkowiak J, Skwarzec B, Bojanowski R and Holm E 1993. Concentration of selected metals in penguins and otherin representative fauna of the Antartica. Science of the Total Environment 138: 281-288

Thompson DR, Furness RW and Heinz GH 1996. Environmental Contaminants in Wildlife: Interpreting Tissue Concentrations. Beyer WN, Heinz GH and Redmon-Norwood AW, New York, USA

Thompson DR, Furness RW and Monteiro LR 1998. Seabirds as biomonitors of mercury inputs to epipelagic and mesopelagic marine food chains. Science of the Total Environment 213: 299-305 
Walsh PM 1990. The use of seabirds as monitors of heavy metals in the marine environment. In: Furness RW and Rainbow PS (eds) Heavy Metals in the Marine Environment. pp 183-204. CRC Press, Boca Raton, USA

Wenzel C and Adelung D 1996. The suitability of oiled Guillemots (Uria aalge) as monitoring organisms for geographical comparisons of trace element contaminants. Archives of Environmental Contamination and Toxicology 31: 368-377 
Table 1: Levels ( $\mu \mathrm{g} \mathrm{g}^{-1} \mathrm{~d} . \mathrm{w}$.) of eight trace elements in three seabirds. Mean values are presented by tissue and by age. sd represents the standard deviation and CV the coefficient of variation. Species/age subgroups sharing the same letter do not differ significantly. The corresponding p-value is given in the last column.

\begin{tabular}{|c|c|c|c|c|c|c|c|c|}
\hline & \multirow{5}{*}{$\begin{array}{c}\text { Species } \\
\text { Age } \\
n\end{array}$} & \multicolumn{2}{|c|}{ Phaethon lepturus } & \multicolumn{2}{|c|}{ Pterodroma baraui } & \multicolumn{2}{|c|}{ Puffinus lherminieri } & \multirow{5}{*}{$\begin{array}{c}\text { p-value } \\
\text { (Fisher's for } \\
\mathrm{X}^{2} \text { ) }\end{array}$} \\
\hline & & Juveniles & Adults & Juveniles & Adults & Juveniles & Adults & \\
\hline & & 4 & 11 & 31 & 5 & 35 & 3 & \\
\hline & & Mean \pm sd & Mean \pm sd & Mean \pm sd & Mean \pm sd & Mean \pm sd & Mean \pm sd & \\
\hline & & $\mathrm{CV} \%$ & $\mathrm{CV} \%$ & $\mathrm{CV} \%$ & $\mathrm{CV} \%$ & $\mathrm{CV} \%$ & $\mathrm{CV} \%$ & \\
\hline & Liver & $\begin{array}{c}37.6 \pm 51.6 \mathrm{ab} \\
137\end{array}$ & $\begin{array}{c}28.0 \pm 18.3 \mathrm{ab} \\
65\end{array}$ & $\begin{array}{c}15.7 \pm 8.5 \mathrm{a} \\
54\end{array}$ & $\begin{array}{c}40.5 \pm 28.8 b \\
71\end{array}$ & $\begin{array}{c}16.7 \pm 8.9 \mathrm{ab} \\
53\end{array}$ & $\begin{array}{c}34.0 \pm 6.8 \mathrm{ab} \\
20\end{array}$ & $<0.0001(4.71)$ \\
\hline \multirow[t]{3}{*}{ As } & Kidney & $\begin{array}{c}26.7 \pm 30.0 \mathrm{ab} \\
89\end{array}$ & $\begin{array}{c}31.2 \pm 25.5 b \\
82\end{array}$ & $\begin{array}{c}11.6 \pm 3.9 \mathrm{ab} \\
34\end{array}$ & $\begin{array}{c}23.1 \pm 7.8 \mathrm{ab} \\
34\end{array}$ & $\begin{array}{c}9.6 \pm 3.4 \mathrm{a} \\
35\end{array}$ & $\begin{array}{c}12.1 \pm 8.3 \mathrm{ab} \\
69\end{array}$ & $0.0001(8.21)$ \\
\hline & Muscle & $\begin{array}{c}8.1 \pm 5.3 \mathrm{ab} \\
62\end{array}$ & $\begin{array}{c}5.9 \pm 2.5 \mathrm{a} \\
42\end{array}$ & $\begin{array}{c}10.5 \pm 3.7 b \\
35\end{array}$ & $\begin{array}{c}16.3 \pm 6.7 b \\
41\end{array}$ & $\begin{array}{c}9.5 \pm 3.8 \mathrm{ab} \\
40\end{array}$ & $\begin{array}{c}12.1 \pm 7.7 \mathrm{~b} \\
64\end{array}$ & $<0.0001(5.21)$ \\
\hline & Liver & $\begin{array}{c}3.40 \pm 2.48 \mathrm{a} \\
73\end{array}$ & $\begin{array}{c}34.9 \pm 19.99 b \\
57\end{array}$ & $\begin{array}{c}6.29 \pm 4.34 \mathrm{a} \\
69\end{array}$ & $\begin{array}{c}66.7 \pm 32.7 \mathrm{c} \\
49\end{array}$ & $\begin{array}{c}2.86 \pm 1.58 \mathrm{a} \\
55\end{array}$ & $\begin{array}{c}55.5 \pm 31.1 \mathrm{bc} \\
56\end{array}$ & $0.0001(46.48)$ \\
\hline \multirow[t]{3}{*}{$\mathrm{Cd}$} & Kidney & $\begin{array}{c}8.71 \pm 6.75 \mathrm{a} \\
77\end{array}$ & $\begin{array}{c}106 \pm 35 b \\
33\end{array}$ & $\begin{array}{c}28.0 \pm 13.97 \mathrm{a} \\
50\end{array}$ & $\begin{array}{c}127 \pm 95.3 b \\
75\end{array}$ & $\begin{array}{c}12.1 \pm 11.6 \mathrm{a} \\
96\end{array}$ & $\begin{array}{c}94.9 \pm 17.8 \mathrm{~b} \\
19\end{array}$ & $0.0001(36.03)$ \\
\hline & Muscle & $\begin{array}{c}0.07 \pm 0.05 \\
140\end{array}$ & $\begin{array}{c}2.37 \pm 1.88 \mathrm{bc} \\
79\end{array}$ & $\begin{array}{c}0.11 \pm 0.03 \mathrm{ab} \\
27\end{array}$ & $\begin{array}{c}9.39 \pm 8.08 \mathrm{~d} \\
86\end{array}$ & $\begin{array}{c}0.04 \pm 0.02 \mathrm{a} \\
50\end{array}$ & $\begin{array}{c}6.04 \pm 5.10 \mathrm{~cd} \\
84\end{array}$ & $0.0001(24.20)$ \\
\hline & Liver & $\begin{array}{c}23.3 \pm 13.6 \\
69\end{array}$ & $\begin{array}{c}16.2 \pm 6.7 \\
41\end{array}$ & $\begin{array}{c}29.4 \pm 49.3 \\
166\end{array}$ & $\begin{array}{c}11.0 \pm 2.7 \\
25\end{array}$ & $\begin{array}{c}11.2 \pm 3.5 \\
31\end{array}$ & $\begin{array}{c}17.7 \pm 4.6 \\
26\end{array}$ & $0.25(1.34)$ \\
\hline \multirow[t]{3}{*}{$\mathrm{Cu}$} & Kidney & $\begin{array}{c}15.1 \pm 4.1 \mathrm{~b} \\
27\end{array}$ & $\begin{array}{c}15 \pm 2.4 \mathrm{~b} \\
16\end{array}$ & $\begin{array}{c}12.7 \pm 3.2 \mathrm{ab} \\
25\end{array}$ & $\begin{array}{c}15.8 \pm 4.7 b \\
30\end{array}$ & $\begin{array}{c}10.0 \pm 5.7 \mathrm{a} \\
57\end{array}$ & $\begin{array}{c}11.5 \pm 0.6 \mathrm{ab} \\
5\end{array}$ & $0.002(4.05$ \\
\hline & Muscle & $\begin{array}{c}18.9 \pm 11.1 \mathrm{abc} \\
59\end{array}$ & $\begin{array}{c}20.1 \pm 9.34 \mathrm{bc} \\
46\end{array}$ & $\begin{array}{c}15.3 \pm 2.9 \mathrm{ab} \\
20\end{array}$ & $\begin{array}{c}26.0 \pm 8.5 c \\
33\end{array}$ & $\begin{array}{c}13.0 \pm 1.4 \mathrm{a} \\
11\end{array}$ & $\begin{array}{c}20.3 \pm 4.9 \mathrm{bc} \\
24\end{array}$ & $0.0001(9.54)$ \\
\hline & Liver & $\begin{array}{c}4168 \pm 3758 b \\
90\end{array}$ & $\begin{array}{c}1420 \pm 855 \mathrm{a} \\
60\end{array}$ & $\begin{array}{c}1242 \pm 576 \mathrm{a} \\
46\end{array}$ & $\begin{array}{c}2016 \pm 858 \mathrm{a} \\
43\end{array}$ & $\begin{array}{c}1378 \pm 554 \mathrm{a} \\
40\end{array}$ & $\begin{array}{c}1158 \pm 914 \mathrm{a} \\
79\end{array}$ & $0.0001(7.29)$ \\
\hline \multirow[t]{3}{*}{$\mathrm{Fe}$} & Kidney & $\begin{array}{c}515 \pm 220 \\
43\end{array}$ & $\begin{array}{c}513 \pm 151 \\
29\end{array}$ & $\begin{array}{c}319 \pm 68 \\
21\end{array}$ & $\begin{array}{c}525 \pm 108 \\
21\end{array}$ & $\begin{array}{c}547 \pm 477 \\
87\end{array}$ & $\begin{array}{c}296 \pm 171 \\
58\end{array}$ & $0.083(2.03)$ \\
\hline & Muscle & $\begin{array}{c}386 \pm 149 \mathrm{~b} \\
39\end{array}$ & $\begin{array}{c}297 \pm 108 b \\
36\end{array}$ & $\begin{array}{c}202 \pm 37 \mathrm{a} \\
18\end{array}$ & $\begin{array}{c}343 \pm 91 b \\
27\end{array}$ & $\begin{array}{c}206 \pm 28 \mathrm{a} \\
14\end{array}$ & $\begin{array}{c}335 \pm 181 \mathrm{~b} \\
54\end{array}$ & $0.0001(13.51)$ \\
\hline & Liver & $\begin{array}{c}0.58 \pm 0.41 \mathrm{a} \\
71\end{array}$ & $\begin{array}{c}1.29 \pm 0.73 \mathrm{a} \\
57\end{array}$ & $\begin{array}{c}1.08 \pm 0.31 \mathrm{a} \\
29\end{array}$ & $\begin{array}{c}29.55 \pm 17 \mathrm{~b} \\
58\end{array}$ & $\begin{array}{c}0.26 \pm 0.07 a \\
27\end{array}$ & $\begin{array}{c}2.22 \pm 0.50 \mathrm{a} \\
23\end{array}$ & $0.0001(55.95)$ \\
\hline \multirow[t]{3}{*}{$\mathrm{Hg}$} & Kidney & $\begin{array}{c}0.44 \pm 0.26 \mathrm{a} \\
59\end{array}$ & $\begin{array}{c}1.34 \pm 0.61 \mathrm{a} \\
46\end{array}$ & $\begin{array}{c}0.55 \pm 0.28 \mathrm{a} \\
51\end{array}$ & $\begin{array}{c}19.84 \pm 12.92 b \\
65\end{array}$ & $\begin{array}{c}0.16 \pm 0.04 \mathrm{a} \\
25\end{array}$ & $\begin{array}{c}1.31 \pm 0.42 \mathrm{a} \\
32\end{array}$ & $0.0001(43.72)$ \\
\hline & Muscle & $\begin{array}{c}0.25 \pm 0.17 \mathrm{a} \\
68\end{array}$ & $\begin{array}{c}0.60 \pm 0.19 \mathrm{a} \\
32\end{array}$ & $\begin{array}{c}0.13 \pm 0.06 \\
46\end{array}$ & $\begin{array}{c}3.74 \pm 2.81 \mathrm{~b} \\
75\end{array}$ & $\begin{array}{c}0.06 \pm 0.01 \mathrm{a} \\
17\end{array}$ & $\begin{array}{c}0.47 \pm 0.14 \mathrm{a} \\
30\end{array}$ & $0.0001(32.08)$ \\
\hline & Liver & $33.4 \pm 14.6 \mathrm{c}$ & $17.0 \pm 8.60 \mathrm{~b}$ & $7.4 \pm 2.6 \mathrm{a}$ & $10.3 \pm 2.8 \mathrm{ab}$ & $11.2 \pm 2.4 \mathrm{~b}$ & $18.4 \pm 5.0 \mathrm{~b}$ & $0.0001(26.08)$ \\
\hline
\end{tabular}




\begin{tabular}{|c|c|c|c|c|c|c|c|c|}
\hline \multirow{4}{*}{ Mn } & & 44 & 51 & 35 & 27 & 21 & 27 & \\
\hline & Kidney & $6.7 \pm 2.2$ & $6.0 \pm 1.6$ & $6.3 \pm 3.1$ & $7.00 \pm 2.5$ & $6.4 \pm 5.2$ & $9.1 \pm 1.1$ & $0.89(0.34)$ \\
\hline & Muscle & $\begin{array}{c}53 \\
1.4 \pm 0.3 \mathrm{a}\end{array}$ & $\begin{array}{c}27 \\
2.4 \pm 0.7 \mathrm{~b}\end{array}$ & $\begin{array}{c}49 \\
1.4 \pm 0.3\end{array}$ & $\begin{array}{c}36 \\
1.7 \pm 0.2 \mathrm{a}\end{array}$ & $\begin{array}{c}81 \\
1.4 \pm 0.2 \mathrm{a}\end{array}$ & $\begin{array}{c}12 \\
2.00 \pm 0.30 \mathrm{ab}\end{array}$ & $0.0001(20.51)$ \\
\hline & Nevore & 21 & 29 & 21 & 12 & 14 & $\begin{array}{c}. .00 \pm 0.00 \mathrm{ao} \\
15\end{array}$ & $0.0001(20.01)$ \\
\hline \multirow{3}{*}{$\mathrm{Se}$} & Liver & $\begin{array}{c}43.0 \pm 20.7 \mathrm{ab} \\
48\end{array}$ & $\begin{array}{c}63.3 \pm 23.2 b \\
37\end{array}$ & $\begin{array}{c}36.2 \pm 7.8 \mathrm{a} \\
22\end{array}$ & $\begin{array}{c}98.5 \pm 20.4 \mathrm{c} \\
21\end{array}$ & $\begin{array}{c}49.9 \pm 13.2 \mathrm{~b} \\
26\end{array}$ & $\begin{array}{c}68.3 \pm 27.1 \mathrm{bc} \\
40\end{array}$ & 0.0001 (19.67) \\
\hline & Kidney & $\begin{array}{c}109 \pm 76 \mathrm{ab} \\
70\end{array}$ & $\begin{array}{c}165 \pm 57 \mathrm{~b} \\
35\end{array}$ & $\begin{array}{c}51.1 \pm 19.4 \mathrm{a} \\
38\end{array}$ & $\begin{array}{c}131 \pm 34 \mathrm{ab} \\
26\end{array}$ & $\begin{array}{c}92.9 \pm 82.3 \mathrm{a} \\
89\end{array}$ & $\begin{array}{c}114 \pm 37.6 \mathrm{ab} \\
33\end{array}$ & $0.0001(6.68)$ \\
\hline & Muscle & $\begin{array}{c}15.5 \pm 6.6 \mathrm{a} \\
43\end{array}$ & $\begin{array}{c}27.0 \pm 9.5 \mathrm{a} \\
35\end{array}$ & $\begin{array}{c}16.0 \pm 3.2 \mathrm{a} \\
20\end{array}$ & $\begin{array}{c}51.5 \pm 19.2 \mathrm{~b} \\
37\end{array}$ & $\begin{array}{c}16.7 \pm 4.5 \mathrm{a} \\
27\end{array}$ & $\begin{array}{c}25.8 \pm 9.8 \mathrm{a} \\
38\end{array}$ & $0.0001(29.63)$ \\
\hline \multirow{3}{*}{$\mathrm{Zn}$} & Liver & $\begin{array}{c}490 \pm 130 \mathrm{c} \\
27\end{array}$ & $\begin{array}{c}244 \pm 99 b \\
41\end{array}$ & $\begin{array}{c}118 \pm 46 \mathrm{a} \\
39\end{array}$ & $\begin{array}{c}267 \pm 95 b \\
36\end{array}$ & $\begin{array}{c}210 \pm 78 b \\
37\end{array}$ & $\begin{array}{c}283 \pm 103 b \\
36\end{array}$ & $0.0001(21.14)$ \\
\hline & Kidney & $\begin{array}{c}166 \pm 34 \mathrm{ab} \\
24\end{array}$ & $\begin{array}{c}193 \pm 41 b \\
21\end{array}$ & $\begin{array}{c}138 \pm 30 \mathrm{a} \\
22\end{array}$ & $\begin{array}{c}204 \pm 56 b \\
27\end{array}$ & $\begin{array}{c}112 \pm 58 \mathrm{a} \\
52\end{array}$ & $\begin{array}{c}161 \pm 31 \mathrm{ab} \\
19\end{array}$ & $0.0001(7.91)$ \\
\hline & Muscle & $\begin{array}{c}125 \pm 42 \mathrm{c} \\
34\end{array}$ & $\begin{array}{c}63 \pm 24 \text { ab } \\
38\end{array}$ & $\begin{array}{c}73 \pm 12 b \\
16\end{array}$ & $\begin{array}{c}81 \pm 28 \mathrm{~b} \\
35\end{array}$ & $\begin{array}{c}55 \pm 8 \mathrm{a} \\
15\end{array}$ & $\begin{array}{c}70 \pm 25 \mathrm{ab} \\
36\end{array}$ & $0.0001(15.25)$ \\
\hline
\end{tabular}


Table 2: Ranking of bird tissues according to their 'ability' to concentrate various trace elements

\begin{tabular}{lcccccl}
\hline & Liver & Kidneys & Muscles & Feathers & Eggs & References \\
\hline Copper & 1 & 2 & 3 & & & Thompson et al., 1996 \\
Zinc & 1 & 2 & 3 & & Furness et al., 1993 \\
Selenium & 1 & 2 & 3 & & Scheuhammer 1979 \\
Mercury & 1 & 2 & 3 & 3 & Furness and Rainbow, 1990 \\
Cadmium & 2 & 1 & 3 & 4 & 4 & Furness and Rainbow, 1990 \\
\hline
\end{tabular}

